\title{
ARCHIVO Y MEMORIA: POLÍTICAS DE LA IMAGEN EN LA POSTDICTADURA ESPAÑOLA
}

\author{
ARQUIVO E MEMÓRIA: POLÍTICAS DA IMAGEM NA PÓS-DITADURA ESPANHOLA
}

Cristina Patricia Sosa ${ }^{1}$

RESUMEN: En este trabajo nos proponemos abordar 143.353 (los ojos no quieren estar siempre cerrados) (2010) del artista español Marcelo Expósito. Su obra funda un dispositivo crítico que plantea una serie de preguntas en torno a lo que se podría llamar una ética de la mirada. En $143.353 \ldots$ se anudan una perspectiva documental experimental y archivística, de modo que la imagen y el archivo devienen arte de la memoria. Definidos como "archivos mutantes" (GARCÍA, 2018), los videos de Expósito dan cuenta de un posicionamiento singular en relación con la política, la historia y la estética. Sus procedimientos más potentes consisten en el montaje y la organización de imágenes de naturaleza variada y de temporalidades heterogéneas. El artista propone nuevas matrices de citación y yuxtaposición en las que aparecen pliegues que tienden a una restauración de la experiencia para activar la memoria. Su posición denota la denuncia de una política de la invisibilidad en la cual la imagen opera como un instrumento mediante el cual la anomia colectiva, la amnesia y la represión son socialmente inscriptas.

Palabras clave: Archivo; memoria; imagen; desaparecidos; dictadura.

RESUMO: Neste trabalho propomos abordar 143.353 (os olhos não querem estar sempre fechados) (2010) do artista espanhol Marcelo Expósito. Sua obra estabelece um dispositivo crítico que sugere uma série de perguntas em redor do que poderia ser chamado de ética do olhar. Em 143.353...uma perspectiva documental experimental e arquivística, é ligada para que a imagem e o arquivo se tornem arte da memória. Definidos como "arquivos mutantes" (GARCIA, 2018), os vídeos de Expósito evidenciam uma posição única em relação à política, à história e à estética. Seus procedimentos mais poderosos residem na montagem e a organização de imagens de natureza variada e de temporalidades heterogêneas. $\mathrm{O}$ artista propõe novas matrizes de citação e justaposição nas quais aparecem dobras que tendem a uma restauração da experiência para ativar a memória. Sua posição manifesta a denúncia de uma política da invisibilidade na qual a imagem atua como instrumento através do qual a anomia coletiva, a amnésia e a repressão são socialmente inscritas.

Palavras-chave: Arquivo; memória; imagem; desaparecidos; ditadura.

\section{El modelo Antígona y el trauma de la dictadura}

Cuando se emplea la violencia contra otros pueblos, también se recurre a ella contra el propio. Antígona (1948) de Bertolt Brecht

\footnotetext{
${ }^{1}$ Maestría en Literatura Argentina de la Universidad Nacional de Rosario-UNR, Argentina. Profesora de Literatura Española en el Instituto de Formación Docente de Villa Mercedes y en la cátedra Literatura Argentina I de la Universidad Nacional de San Luis-UNSL, Argentina.
} 
Porque la imagen verdadera del pasado es una imagen que amenaza con desaparecer con todo presente que no se reconozca aludido en ella. "Tesis V", en Sobre el concepto de historia. Walter Benjamin.

En este pueblo hay más muertos fuera del cementerio que dentro ${ }^{2}$

En la primera jornada del Decamerón, Boccaccio cuenta que era tan grande la multitud de muertos por la peste bubónica que, cuando no alcanzó la tierra sagrada para dar sepultura siguiendo "la antigua costumbre", se procedió a hacer grandes fosas: "en las que se ponían a centenares los que llegaban, y en aquellas estibas, como se ponen las mercancías en las naves en capas apretadas, con poca tierra se recubrían hasta que se llegaba a ras de suelo". Desde que se detectaron los primeros casos en noviembre de 2019 en la ciudad de Wuhan, la covid-19 alteró al mundo en muchos sentidos, incluso en relación con el ritual de la muerte ${ }^{3}$.

Abundan los artículos que hablan de las víctimas de la enfermedad, algunos se preguntan si los cadáveres pueden contagiar el virus, mientras que otros dan cuenta de la saturación de los sistemas de entierros provocada por la pandemia. Este nuevo orden mundial ha significado una transformación de lo vital y estableció nuevos imaginarios de la muerte en los que prima la despersonalización ya que se imponen velorios remotos, breves, higiénicos, en los que no se puede abrazar o manifestar con proximidad las condolencias, sin lamento colectivo ni un llanto presencial. Además, en los últimos tiempos han proliferado las imágenes de cadáveres tirados en las calles de Guayaquil, nos impactó el video de los camiones cargados de cadáveres que cruzaron Italia, hemos visto la isla-fosa de Nueva York (donde se cavaron zanjas para hacer entierros masivos) y nos enteramos de la existencia de una pista de patinaje que fue convertida en morgue en Madrid. En este sentido, la periodista mexicana Marcela Turati advierte que:

como una manera de sobrellevar las reglas sanitarias comienzan a surgir Antígonas - la heroína de la mitología griega que desafía las leyes para enterrar a su hermano- que intentan restaurar el derecho de las personas fallecidas a ser recordadas, a tener despedidas dignas ${ }^{4}$.

Precisamente de la figura de la célebre tragedia de Sófocles deriva la Antígona de Bertolt Brecht. Esta última funciona, junto con Santiago Matamoros y el Guernica de Picasso, como uno de los tres modelos de 143.353... Esta obra concluye una serie de videos-ensayo que Marcelo Expósito tituló Entre sueños. Ensayos sobre la nueva imaginación política. Junto con Primero de Mayo (la ciudad-fábrica) (2004), La imaginación radical (carnavales de resistencia) (2004), Frivolidad táctica + ritmos de resistencia (2007) y No reconciliados (nadie sabe lo que un cuerpo puede) (2009) el artista construye una obra de difícil clasificación, en la que se anudan el trabajo documental, la experimentación y el archivo. Estos videos, que permiten diversos niveles de lectura, se

\footnotetext{
${ }^{2}$ Estas palabras corresponden al testimonio de un paisano que colaboró con Silva Barrera en la ubicación de la fosa en la que se hallaban los restos de su abuelo paterno desaparecido en 1936. Disponible en: <http://www.derechos.net/esp/algomas/silva.html > Acceso en: 21 de mayo de 2020.

${ }^{3}$ En rigor de verdad, el ritual de la muerte se ha visto trastocado durante muchas crisis a lo largo de la historia. Sin embargo, el desconocimiento del comportamiento de la enfermedad por coronavirus ha llevado a extremar las precauciones en el tratamiento de los cadáveres.

4 Artículo publicado en el periódico The New York Times. Disponible en: <https://www.nytimes.com/es/2020/05/05/espanol/opinion/muertes-coronavirus.html?smid=tw-share > Acceso en: 21 de mayo de 2020.
} 
constituyen como una práctica que tiene potencialmente efectos políticos.

El quinto capítulo de la serie, $143.353 \ldots$, comienza con una cuenta regresiva y con una cita de Serge Daney sobre No reconciliados (1965) de Straub y Huillet: "Donde hay resistencia allí se debe filmar". Se presenta como un video en 3 actos sobre la política de la imagen asociada al genocidio perpetrado entre las décadas del 1930 y 1940 en España. Cada uno de los actos presenta la definición de los conceptos que le dan título como una manera de dejar asentado desde qué perspectiva se realiza este trabajo reflexivo.

Después de un prólogo de aproximadamente 10 minutos, empieza el Acto 1: Recuperación/restauración, con la filmación de un trabajo de excavación. Luego de un par de minutos de observar cómo un hombre remueve tierra, al finalizar, se retira y se devela que lo que ha encontrado es un esqueleto humano. Expósito se empeña en problematizar la operación de localización de las fosas y la documentación de una exhumación, cuestiona el tratamiento que la televisión ha dado a dicho proceso, con la combinación del distanciamiento y frialdad propios de la presentación de datos e información demasiado técnicos con una tendencia a la multiplicación de voces y puntos de vista. Como respuesta señala una sola experiencia, la de Emilio Silva Barrera, y un acercamiento despojado y silencioso al trabajo arqueológico para alcanzar una distancia justa 5 .

FIGURA I. Primeras imágenes del Acto I. Recuperación/restauración
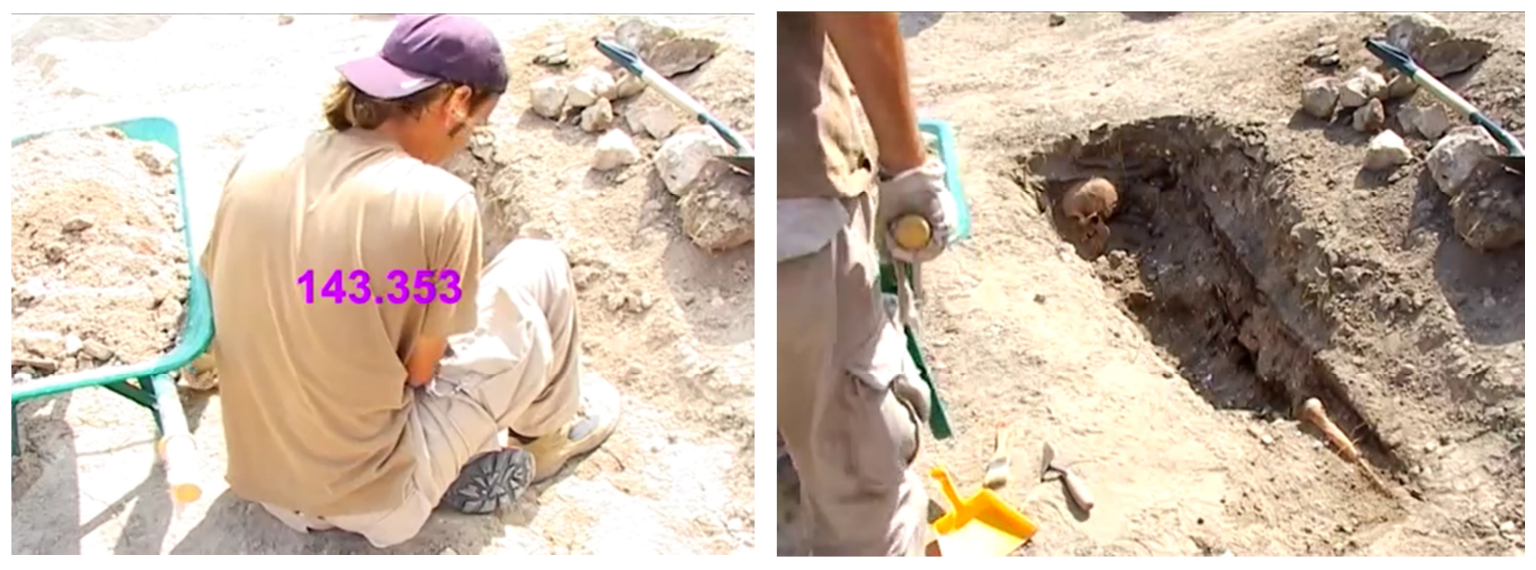

El segundo acto, Asociación/excavación comienza con la imagen de un ojo que se mueve de manera rápida. Expósito explica que para tratar el estrés postraumático se implementan: "técnicas que imitan el movimiento ocular rápido buscan la estimulación cerebral bilateral que facilitaría reprocesar los pensamientos para producir cambios en las estructuras de la memoria y las respuestas asociadas”. Luego se proyecta una serie de imágenes de archivo que se engloban en un círculo y se alternan una velocidad de reproducción lenta y rápida.

En una especie de repaso de acontecimientos como las primeras elecciones de la postdictadura, imágenes de 1976 en las que un hombre lee un diario cuyo titular central es "Adiós dictadura", 1975 y el funeral de Franco, con la grabación del cadáver y de las personas

\footnotetext{
${ }^{5}$ Cabe aclarar que esta crítica de Marcelo Expósito al tratamiento de las víctimas se expresa de manera detallada, junto con la información técnica del video y su fundamentación teórica en la explicación de los videos que el artista preparó para la exposición en el Museo Nacional Centro de Arte Reina Sofía. Disponible en: <http://marceloexposito.net/pdf/exposito_143353.pdf > Acceso en: 21 de mayo de 2020.
} 
que lo despiden, así como el discurso del rey Juan Carlos. Asimismo, hay imágenes de 1974, 1973, 1969, 1968, de 1965 con la visita de The Beatles, de 1964 en donde se ve al dictador pescando y cazando, también se muestra un piso lleno de animales muertos, continúa con videos de 1956, 1948, 1942, 1940, 1938, 1937 con la destrucción de Guernica, hasta llegar a 1936.

Cada uno de los acontecimientos es mostrado con la fecha como única referencia para el espectador, en un orden temporal que va en sentido inverso. Ese desplazamiento hacia atrás puede interpretarse como una voluntad de horadar el pasado, de tomar un conjunto de materiales que han sido presentados por los medios de comunicación, pero esta vez reinterpretados a luz de la búsqueda de verdad de los familiares de los desaparecidos de la última dictadura. A veces resulta vago el acontecimiento que se expone porque apenas alcanzan a verse fragmentos de una imagen que no logra apreciarse con claridad.

Expósito se apropia del archivo con el objetivo de dominarlo, organizarlo y comprenderlo, bajo la premisa de que es un laberinto compuesto tanto de intervalos y huecos como de material observable. Emprende así la tarea de ordenar fragmentos de cosas supervivientes, que son anacrónicas porque provienen de diversos tiempos y espacios (DIDIHUBERMAN, 2007). Esa reunión de imágenes que se orientan hacia atrás y hacia adelante, en un movimiento pendular que redefine su valor de uso revela los efectos de sentido peculiares que se desprenden de una disposición reordenada que colisiona con una narrativa normalizadora. El archivo y la imagen no muestran un absoluto, sino apenas un fragmento en el que resplandece una verdad pasajera que, según Didi-Huberman (2007): "Precisa de una construcción analítica, de un montaje del saber, para otorgar, como interpretación y arqueología, consistencia epistémica a estos jirones de saber". De manera que la imagen es una huella visual del tiempo, un arte de la memoria que precisa mantenerse ardiente.

FIGURA II. El ojo y el material de archivo
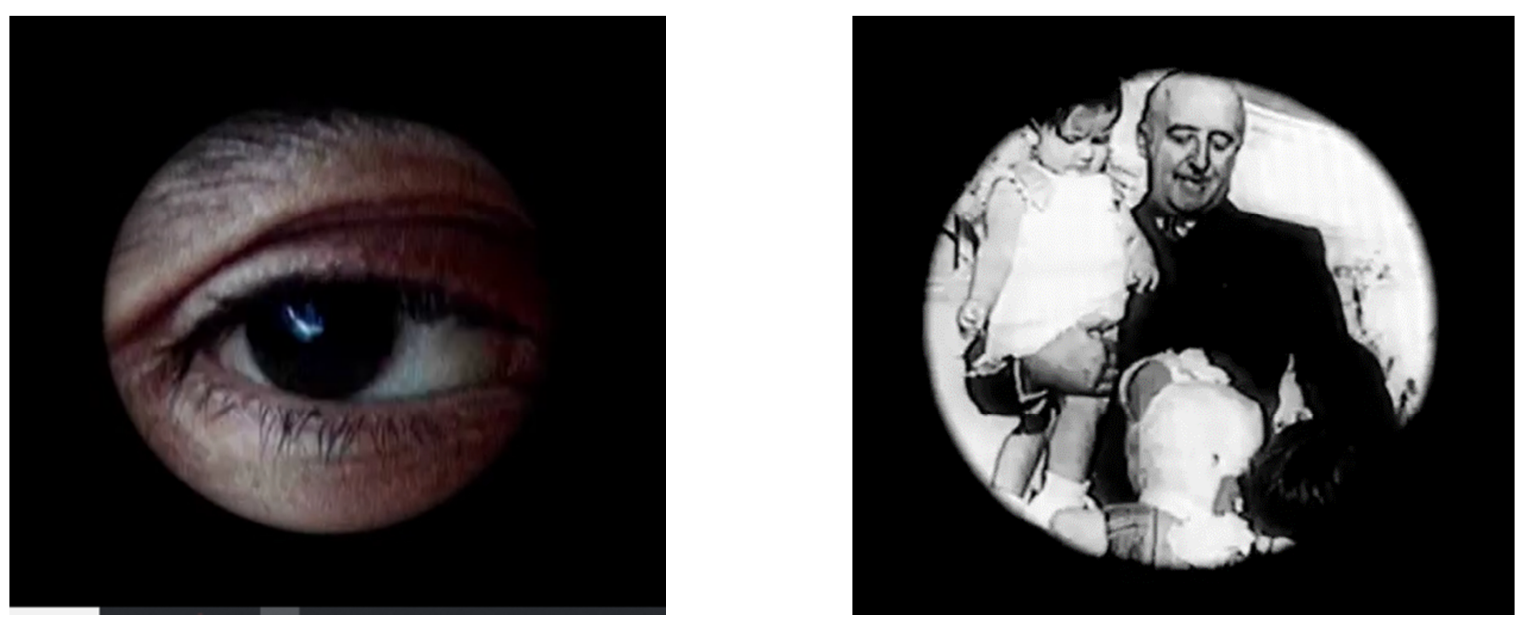

En el acto final, que se llama Memoria histórica/exhumación, una placa postula: "lo que se hace necesario es volver a escribir la historia a la luz de los acontecimientos negados $\mathrm{u}$ omitidos no tenidos en cuenta”. Plantea la intención de concretar un trabajo terapéutico y para eso se dirige al Monasterio de Uclés lugar donde se ha montado un campamento arqueológico cuya acción se presenta en largas secuencias sin música, pero con cortes de negro que imitan el parpadear de los ojos. Se informa al espectador que entre 2005 y 2007 se encontraron 439 cadáveres en una superficie de 3000 metros cuadrados. Tras mostrar 25 minutos de trabajo en 
tiempo real, en los que hemos asistido a gran parte del proceso, reparamos que este termina cuando una arqueóloga que forma parte de la Asociación de Recuperación de la Memoria Histórica de Cuenca completa una planilla.

Vemos trabajar al equipo desde la distancia justa que le interesa a Expósito. De esa manera, observamos una serie de carteles que hablan del trabajo que se está haciendo y que explica que lo que lo motiva es la intención de darle trato humano a las personas enterradas allí. Señala la necesidad de que sean devueltos a su comunidad y, si ello es posible, a sus familiares. Los carteles indican, además, que allí fueron enterrados hombres y mujeres en diferentes circunstancias, porque el Monasterio funcionó como Hospital de heridos (de los cuales hay registro de 200 cadáveres) y luego como Prisión de la represión (con 160 fusilados y 150 víctimas de actos violentos, penurias, hambre y enfermedades).

Resalta en uno de los carteles una consigna escrita en letras mayúsculas que dice: "NO REMOVER EL PASADO”. Se explica que se propone la reintegración moral y social de víctimas que han estado enterradas sin identificación durante 6 décadas. Expósito finaliza ese acto con la imagen de Santiago Matamoros y con una placa negra que cita un fragmento de la obra de Brecht: "por ello quiero que nadie llore su muerte y que no tenga tumba que ninguno se apiade de su cuerpo. Otros cuerpos destrozados yacerán sin tumba por millares en torno de aquel que no tuvo sepultura”.

Sin dudas, el momento de mayor fuerza en esa última parte lo constituye el testimonio de Emilio Silva Barrera quien se presenta como un ciudadano de 44 años a cuyo abuelo paterno han desaparecido. Relata que en 1999 comenzó su investigación, después de advertir que el 16 de octubre de 1998, cuando se procedió a cumplir con la orden de detener a Pinochet en Londres para enviarlo a Chile a dar respuesta a la justicia, los españoles celebraron que las víctimas del dictador pudieran tener una acción reparadora por parte del estado, mientras que en su país no parecía haber una voluntad política de hacer algo semejante.

Eso lo motivó a escribir un artículo que tituló "Mi abuelo también fue un desaparecido" en el diario La Crónica de León el 8 de octubre de 2000. En ese texto no solo contó su historia familiar, sino que convocó a todos los que hubieran vivido una experiencia semejante a acercarse con el objetivo de empezar a remover el pasado para encontrar respuestas en el presente. Como una especie de Antígona moderna, Silva Barrera enfrentó la advertencia que su padre le hizo cuando era pequeño: "De esto no se habla afuera de casa”. Una indicación que alzaba una frontera imaginaria marcada por la puerta de su hogar.

Como consecuencia de esa publicación, fue contactado por el arqueólogo Julio Vidal quien se ofreció junto con 5 arqueólogos, un médico y una antropóloga forenses para exhumar los restos que se encontraban en una fosa en la que podría estar su abuelo. Encontraron 13 cadáveres, pero para poder identificarlos de manera fehaciente tuvieron que rastrear en archivos, fue entonces cuando descubrieron que no era posible hallar los documentos de los nombres de quienes estaban enterrados allí. A pesar de esos obstáculos, gracias al testimonio de gente de la zona y a algunos elementos encontrados juntos a los restos fue posible identificar a las víctimas. De esa manera, su abuelo se convirtió en la primera víctima identificada con un estudio de ADN y gracias a eso ahora sus restos se encuentran enterrados con los de su esposa.

\section{El montaje de los archivos mutantes}

A diferencia de lo que fue la experiencia de la postdictadura en algunos países de 
Latinoamérica, en España las víctimas vivieron 40 años gobernados por los asesinos en un régimen que terminó con la muerte del dictador y no debido al proceso de resistencia y lucha que ejerció el pueblo. Esto provocó una especie de psicosis colectiva que llevó a muchos a vivir como si eso no hubiera sucedido. Para Silva Barrera, los muertos de la dictadura no son fantasmas, son seres reales, muertos que regresan. Su búsqueda y recuperación convierte en algo político la experiencia y funciona como una radiografía de la democracia que da cuenta de la ausencia de algunos huesos.

Precisamente, así comienza 143.353..., con la radiografía de unas articulaciones y con un fragmento de Le squelette joyeux (1897) de Lumière que Expósito utilizó ya en El año en que el futuro acabó (comenzó) (2007). Ese video constituye una cuenta atrás visual, en la que utiliza mecanismos no discursivos más cercanos al sueño que al relato lo cual evidencia que en la poética del realizador se concibe que las imágenes se convierten en un instrumento de memoria cuando se trabaja sobre ellas.

FIGURA III. Le squelette joyeux (1897) de Louis y Auguste Lumière

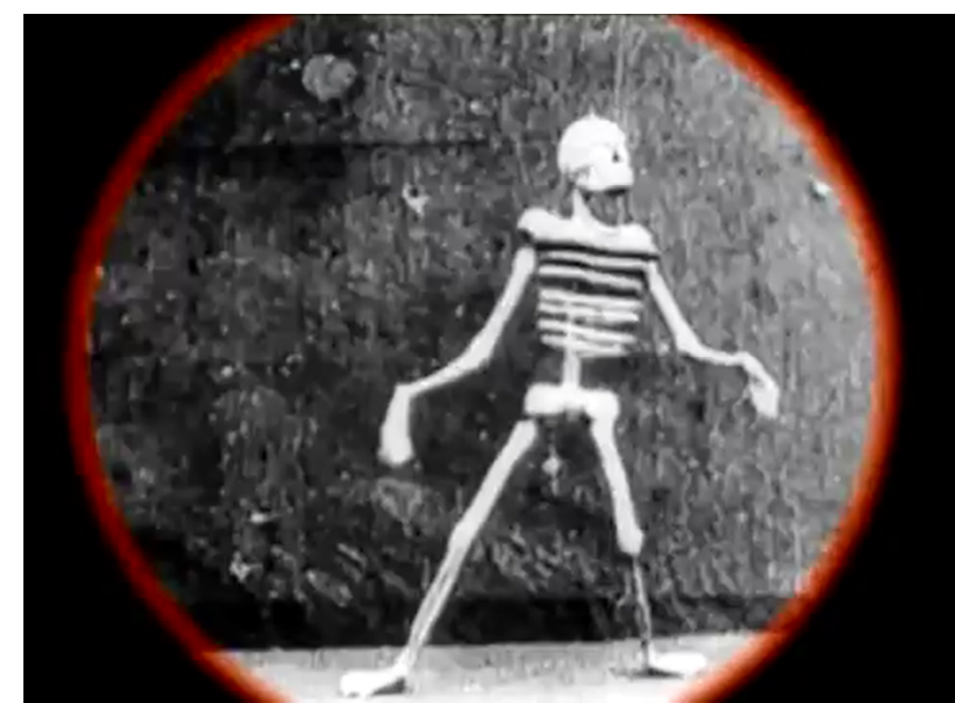

También en un trabajo anterior se sirve del testimonio. La tierra de la madre (1994) ${ }^{6}$ de Expósito y José Antonio Hergueta es un video de 21 minutos en el que se cuenta la historia de Conchita Eguidazu y con ella la de un conjunto de niños que huyeron de España durante la Guerra Civil. Los realizadores presentan una crítica a la espectacularización del horror de la guerra. En el relato de la figura central se cifra la experiencia de muchos niños y jóvenes que encontraron en el exilio la única alternativa para sobrevivir a la violencia del inminente régimen de Franco.

Los materiales que se utilizan son de naturaleza variada: cartas, pasaportes, postales, fotografías, videos y un filme de Nemesio Sobrevila realizado en 1937, Guernika, el cual da cuenta de la destrucción de esta ciudad vasca. En un fragmento de la película se afirma que su objetivo es actuar en contra de quienes tienen el "propósito de robar a la historia estos hechos mediante la eliminación de sus imágenes”. Una idea estrechamente vinculada con la tesis de Benjamin que postula que el recuerdo es revolucionario en la medida en que rescata un

\footnotetext{
${ }^{6}$ Disponible en: <https://www.hamacaonline.net/titles/la-tierra-de-la-madre/ > Acceso en: 21 de mayo de 2020.
} 
fragmento del pasado que se encuentra en peligro.

El video finaliza con un mensaje de la hija de Franco. Mientras el dictador se ubica detrás de ella y recita en voz baja el mensaje, Carmencita le pide a Dios que los niños españoles no conozcan el sufrimiento y la tristeza de quienes están en manos de los enemigos de su patria y finaliza con una exclamación: “¡Viva España!”. La incorporación de este fragmento revela una de las claves de lectura medulares de los trabajos de Expósito: la ironía.

Apela a este recurso también en Los demonios familiares ${ }^{7}$ (1990-1994), obra que tiene tres partes: Los libros de las piedras, Tierra prometida y Combat del somni. La segunda parte entremezcla fragmentos de la película Alba de América (film dirigido por Juan de Orduña en 1951) con imágenes referidas al atentado de ETA que terminó la vida del almirante Carrero Blanco en 1973 y alusiones a la ejecución de Salvador Puig Antich y Heinz Chez por garrote vil en 1974. El personaje de Cristóbal Colón llega a América y, mientras sus hombres comienzan a recorrer el espacio, dice: "Como hermanos vinimos". Esta frase se repite y se distorsiona grotescamente mientras se intercalan las violentas imágenes que referimos antes.

La hipótesis que parece atravesar su obra sostiene que los relatos instituidos sobre la transición democrática y los años posteriores se definen y se sostienen por una representación visual sobrecodificada que oculta y manipula la comprensión de los hechos históricos que dice representar. Esto lleva a Expósito a apelar al carácter onírico del dispositivo cinematográfico, por eso crea videos que aspiran a descomprimir el "inconsciente colectivo" de las imágenes de un país de memoria frágil.

Como explica acerca de Los demonios familiares, el montaje busca provocar un extrañamiento, mediante yuxtaposiciones que recrean mecanismos oníricos de condensación, proyección y desplazamiento. Estos recursos no discursivos son más cercanos al sueño que al relato y evidencian una observación cuidadosa del detalle en imágenes de naturaleza variada cuya distorsión, actúa como una inevitable puesta en cuestión del archivo. Expósito subvierte el orden del archivo y exhibe, así, sus sistemas de operación mediante los mismos medios en que estos se llevan a cabo. Esta es una práctica artística que se orienta en una dirección que pretende visibilizar el valor de la imagen para interrogar los sentidos de la historia y la política.

En relación con lo señalado, García (2018) considera que la potencia estético-política de los trabajos de Expósito surge de la manera en que une la reflexión sobre el horror del siglo XX con una posición comprometida que se apoya tanto en la participación de movimientos sociales como en el despliegue de estrategias creativas de resistencia. Destaca el carácter militante de su producción y afirma que hay que preguntarse por la posición de la obra dentro del movimiento global. Cuando atiende a la gramática del montaje de No reconciliados... y 143.353 ... observa que algunas de las estrategias más utilizadas son:

la ausencia de un relato y de una cronología ordenadora, el juego con la composición visual puramente formal o ficcional, el amplio uso de citas documentales y artísticas (plásticas, fotográficas, cinematográficas, musicales, literarias), el desmoronamiento del límite entre documento y ficción, la

\footnotetext{
${ }^{7}$ El título está basado en Los demonios familiares de Franco de Manuel Vázquez Montalbán. En esa obra, el autor remite a una expresión con la que el dictador denominaba a lo que consideraba problemático en España: la anarquía, el individualismo, la crítica negativa y el extremismo, pero también usaba esa expresión para referirse a lo que consideraba diablos históricos como el separatismo, la masonería y el comunismo. Disponible en: <https://www.hamacaonline.net/titles/los-demonios-familiares-1-los-libros-por-las-piedras-2-tierra-prometida-3combat/ > Acceso en: 21 de mayo de 2020.
} 
constante separación y puesta en roce entre los elementos (la permanente interrupción entre los diversos segmentos del video, o entre sus diversos elementos sensibles -centralmente la imagen y la música), el uso de textos (citas diversas y fragmentarias, y despojadas de sus títulos de propiedad o autoría) que interrumpen el flujo de imágenes o se sobreponen a ellas, la intercalación de entrevistas, etc. En cierta medida, podría decirse que la interrupción (visual, temporal, entre elementos, etc.) es la matriz que une estas diversas estrategias -y que opera como la principal política de la forma: la interrupción como la inscripción de la discordia en lo común estético (pp. 1819).

Por lo tanto, el montaje le permite a Expósito desgarrar la historia oficial para poder construir una historia de los vencidos. Estos videos se interrogan por sus propias condiciones de enunciación y exposición debido a que, cuando se pierde la confianza en el registro, emerge una reflexión sobre las propias operaciones formales (GARCÍA, 2018). En este sentido, otro recurso central de esta obra es el desquiciamiento del tiempo, esto es, el desorden de la continuidad. Expósito diseña dispositivos modulares con elementos mínimos de gran movilidad, máquinas proteicas de un carácter transformable y adaptable a situaciones diversas, archivos mutantes:

Los archivos son aquí mapas policéntricos de la emergencia, máquinas de
refuncionalización (de brechtiana Umfunktionierung). El enlazamiento de
documentalismo y experimentalismo es una estrategia posible de articulación,
en la gramática del disenso (en la poética del montaje), de memoria y
revolución: una memoria sin melancolías, y una revolución no olvidada de sus
ruinas -electropolíticas de la conjuración: en los videos de Marcelo Expósito,
los archivos mutantes atesoran los documentos del porvenir (GARCÍA, 2018,
p. 34).

\section{De tiempos heterogéneos y la resistencia de la mirada}

Hay consenso en que tanto la imagen como el archivo rigen desde hace un par de décadas como un paradigma instalado y como marca generativa de gran parte de la producción del universo estético, cotidiano, político e histórico (DIDI-HUBERMAN, 2007). Autores como Hal Foster (2016) o Anna María Guasch (2011) observan que se asiste actualmente a un giro al archivo (archival turn) que en la cultura contemporánea afecta e impregna las prácticas artísticas.

Cuando Derrida (1997) indaga el sentido de la palabra archivo, observa que confluyen en ella las ideas de comienzo y de ejercicio de una autoridad (esto es, de imposición de un orden social). Por lo tanto, en ella se integran dos clases de orden, primero el secuencial y luego el de mandato. Asimismo, el concepto de archivo (que viene del latín archivum y este del griego arjeion término que está emparentado a su vez con el verbo arjo: yo mando, yo gobierno, soy jefe) abriga la memoria del sustantivo griego arkhé. El término griego Arkheion, que significa casa o domicilio, designaba la residencia de los magistrados superiores, es decir, de los arcontes. Por la autoridad que detentaban, allí se depositaban los documentos oficiales y eran ellos los únicos que tenían derecho y competencia hermenéutica: "Tienen el poder de interpretar los archivos" (DERRIDA, 1997, p. 10).

Expósito disputa con su trabajo la interpretación de las imágenes del pasado, por lo que 
extrema la productividad de una noción que no es solo el soporte de su obra, sino la esencia misma de un posicionamiento en relación con la memoria, la historia, la política y los modos de dar cuenta de ellas. Parte de la idea de que la lógica del archivo exige un modo de lectura propio que se asienta en la exposición del montaje y en la exploración de sus potencialidades estéticopolíticas. El autor se presenta como parte de una generación que comenzó a madurar biográficamente entre la transición y los primeros años de gobierno del partido socialista. Fueron testigos durante los años 80 de la institucionalización progresiva del concepto de lo político, de su congelación, cosificación y desprestigio. Durante la década siguiente se propusieron la apertura del concepto porque aspiraban a una repolitización, a la recuperación de su fuerza.

Cuando la noción de archivo comenzó a expandir su campo de aplicación, algunos autores comenzaron a hablar de una fiebre de archivo que implicó un desplazamiento de la sacralización a un desorden que se propuso "poner en cuestión el canon, las instituciones y las historias construidas" (GIUNTA, 2010, p. 31). Frente a la amnesia instaurada por el poder, Expósito impone imágenes que testimonian el olvido, con la creación de un contra archivo visual en el que prima la copresencia de temporalidades heterogéneas que obliga a una restauración de la experiencia para activar la memoria.

Establecer este carácter construido requiere asumir la tarea de definir una ética de la mirada que dé cuenta de que el archivo no puede ser concebido como un reflejo del acontecimiento, así como tampoco una demostración, en realidad es una manera de comprender que será trabajada mediante cortes y entrelazamientos con otros archivos (DIDIHUBERMAN, 2007). En relación con lo señalado, esa voluntad de conectar puede develar un dejo de paranoia, ya que esta es una práctica de conexiones forzadas y de combinaciones inesperadas. Pero de la mano de la paranoia aparece una ambición utópica, un "deseo de convertir tardanza en devenir, de recuperar visiones fallidas en escenarios posibles de tipos de relaciones sociales alternativos" (FOSTER, 2016, p. 123). En este sentido, Sekula (2003) señala que: "Nuestro problema, como artistas e intelectuales que vivimos cerca, pero no en el centro, de un sistema global de poder, será ayudar a prevenir la supresión de ese testimonio por parte de textos más autoritarios y oficiales" (p. 186).

Cuando en una entrevista de 2012 le preguntaron a Marcelo Expósito cómo producir una imagen política, el director respondió que solo era posible con la voluntad de articular la pulsión material de imágenes con las condiciones externas, gracias a las invenciones formales radicales que surgen de tomar en consideración aspectos no consustanciales de la producción de imágenes. Entiende la función de la práctica artística en contextos postdictatoriales como un proceso lindante con lo terapéutico. El arte produce pequeños dispositivos, modelos donde se pueden reconfigurar las subjetividades sociales, hacen posible un desanudamiento del cuerpo o de un desaprendizaje del temor.

En la primera parte de 143.353... Expósito explica que el 7 de diciembre de 1941 el Tercer Reich alemán estableció el modelo de práctica de desaparición forzada de personas. A quienes se desaparecía de ese modo y se los llevaba a campos de concentración o exterminio se los identificaba con la sigla NN, que provenía del Decreto Noche y Niebla (nacht und nebeler lass). Luego cuenta que en Argentina en 1978 alguien se atrevió a preguntar adónde llevaban a los detenidos durante la dictadura cívico-militar y la respuesta que obtuvo fue: "Van a la niebla de ninguna parte”. Finalmente, destaca que, en 1936, en España, el ejército sublevado se adelantó tanto al decreto noche y niebla como a la experiencia latinoamericana, subraya así el carácter prematuro de ciertas prácticas violentas de la experiencia fascista en su país. 
El jueves 7 de mayo, falleció aquejado de la covid-19 el expolicía Antonio González Pacheco conocido como Billy, el Niño. González Pacheco fue un símbolo de la represión franquista en los últimos años de la dictadura. También fue símbolo de la impunidad ya que nunca fue juzgado, ni se le retiraron las medallas que recibió por los atroces actos que sus víctimas han denunciado. Hubo una puja de fuerzas entre las justicias de España y de Argentina en relación con este caso porque fue necesaria la intervención de la jueza María Servini, quien dictó una orden internacional de búsqueda y captura por delitos de lesa humanidad. Mientras que en España ni siquiera fue detenido pese a la nota de Interpol. Solo fue llamado a declarar y la Audiencia Nacional declaró prescrita la causa desde hacía más de treinta años.

Ya hemos señalado que tres modelos ordenan esta obra de Marcelo Expósito. El modelo Santiago apunta a indagar el mito de la hispanidad en tanto figura que ayudó a derrotar a los musulmanes en lo que desde una perspectiva cristiana se consideró una "Reconquista". Da cuenta de un arquetipo que se transformó en América en marca del genocidio colonial cuando deviene Santiago Mataindios. Puede ser interpretado, finalmente, como un emblema del asesinato sistemático de españoles por parte del estado nacional. El modelo Antígona, por su parte, consiste en la acción de multiplicar la desobediencia tanto a las leyes escritas (nos referimos a la Ley de Amnistía de 1977 que funcionó como ley de "punto final") como a las no escritas, las que surgieron y se sostuvieron a lo largo de décadas en el imaginario de las familias de las víctimas del fascismo. El modelo Guernica devuelve a la imagen su condición de artefacto de propaganda. Cuando la pintura de Picasso deja de concebirse solo como una expresión artística y comienza a considerarse como lo que fue en su origen: una denuncia del genocidio fascista moderno.

Esta obra pone el acento en lo participativo con una estética vinculada a prácticas culturales innovadoras que buscan subvertir un orden establecido. Cuestiona el lugar y las funciones de las instituciones existentes y de los dispositivos ideológicos que las sostienen con la construcción de un espacio de ruptura e insumisión en el horizonte posfranquista. Hay una voluntad crítica que da cuenta de años de fuerte crisis de identidad y que pretende la redención de la memoria de las víctimas.

Silvia Schwarzböck (2016) sostiene que a la postdictadura ${ }^{8}$ hay que adentrarse por la estética ya que es una exigencia de su objeto, propio del género de terror. Concluye su ensayo con la siguiente idea: "Los espantos podrían ser-si se los lee con Marx-los muertos que pesan como una pesadilla sobre la conciencia de los vivos. No obstante, existen en tiempo presente". Al recorrer la trayectoria de la producción de Expósito un conjunto de problemas reaparece como obsesiones del artista. Se trata de elementos que iluminan acerca de una ética de la mirada y un modo singular de concebir el trabajo artístico asociado con la labor docente, de investigación, editorial y de la actividad política partidaria. Tres palabras cierran $143.353 \ldots$ : verdad, justicia y reparación, objetivos que dan forma y sentido tanto al video como a las vidas de las víctimas.

\section{Referencias}

BENJAMIN, W. Tesis sobre el concepto de historia. Disponible en: <http://arteyanalisis.com.ar/wp-content/uploads/2016/04/Sobre-el-concepto-de-historia-

\footnotetext{
${ }^{8}$ La filósofa aborda el caso argentino, pero bien vale pensarlo en la producción artística de España.
} 
Benjamin.pdf> Acceso en: 21 de mayo de 2020.

DERRIDA, J. Mal de archivo. Una impresión freudiana. Madrid: Editorial Trotta, 1997.

DIDI-HUBERMAN, G. El archivo arde/ Das Archiv brennt. En: .; EBELING, K. (Eds.).

Das Archiv brennt. Berlin: Kadmos, pp. 7-32. Traducción de Juan Ennis para la cátedra de Filología Hispánica. Disponible en: <http://filologiaunlp.wordpress.com/bibliografia/>, 2007. Acceso en: 21 de mayo de 2020.

FOSTER, H. El impulso de archivo. Traducción de Constanza Qualina Nimio (N 3), pp. $102-$ 125, septiembre 2016. Disponible en http://papelcosido.fba.unlp.edu.ar/nimio Facultad de Bellas Artes Universidad Nacional de La Plata. Acceso en: 21 de mayo de 2020.

GARCÍA, L. I. La comunidad en montaje. Imaginación política y postdictadura. Buenos Aires: Prometeo Libros, 2018.

GIUNTA, A. Objetos mutantes: sobre arte contemporáneo. Santiago de Chile: Ed. Palinodia, 2010.

GUASCH, A. Arte y archivo, 1920-2010: Genealogias, tipologías y discontinuidades. Madrid: Akal, 2011.

SCHWARZBÖCK, S. Los espantos. Estética y postdictadura. Buenos Aires: Cuarenta Ríos, 2016.

SEKULA, A. El cuerpo y el archivo. En: PICAZO, G.; RIBALTA, J. (ed.). Indiferencia y singularidad: la fotografía en el pensamiento artístico contemporáneo. Barcelona: Gustavo Gili, 2003.

Recebido em: 21/05/2020

Aceito em: 07/07/2020 